\title{
Description of Verrucosispora qiuiae sp. nov., isolated from mangrove swamp sediment, and emended description of the genus Verrucosispora
}

Correspondence

Ying Huang

huangy@im.ac.cn

\author{
Lijun Xi, Limin Zhang, Jisheng Ruan and Ying Huang
}

\author{
State Key Laboratory of Microbial Resources, Institute of Microbiology, Chinese Academy of \\ Sciences, Beijing 100101, PR China
}

The genus Verrucosispora, which was established by Rheims et al. (1998) as a member of the family Micromonosporaceae, has drawn much attention in recent years because it has proved to be a source of potential antitumour compounds such as abyssomicin, gifhornenolones and proximicins (Bister et al., 2004; Keller et al., 2007; Riedlinger et al., 2004; Schneider et al., 2008; Shirai et al., 2010). At the time of writing, this genus comprised three species with validly published names, Verrucosispora gifhornensis, Verrucosispora lutea and Verrucosispora sediminis, with type strains isolated from peat bog, mangrove sediment and deep-sea sediment, respectively (Rheims et al.,

Abbreviations: DPG, diphosphatidylglycerol; PE, phosphatidylethanolamine; PIM, phosphatidylinositol mannoside; PL, unknown phospholipid.

The GenBank/EMBL/DDBJ accession numbers for the 16S rRNA gene sequence of strain RtIII47 ${ }^{\top}$ and the gyrB gene sequences of strain RtIII $47^{\top}$, Verrucosispora lutea YIM 013 ${ }^{\top}$, Verrucosispora sediminis CGMCC 4.3550', Verrucosispora gifhornensis JCM $10457^{\top}$, Jishengella endophytica CGMCC $4.5597^{\top}$ and Plantactinospora mayteni YIM $61359^{\top}$ are EU427445, HO199219, HM134795, HO199220, HM134796, JN207849 and JN207850, respectively.

Two supplementary figures and a supplementary table are available with the online version of this paper.
1998; Liao et al., 2009; Dai et al., 2010). Marine environments seem to be a good source of both novel species of this genus and unique natural products.

During the course of selective isolation of actinomycetes present in mangrove soil in China, hundreds of Micromonosporalike actinomycetes were isolated (Qiu et al., 2008). Strain RtIII $47^{\mathrm{T}}$ is one of them, and showed morphological characteristics typical of the family Micromonosporaceae. In this paper, we report the taxonomic characterization and classification of this isolate, and propose that it represents a novel species of the genus Verrucosispora.

Strain RtIII $47^{\mathrm{T}}$ was isolated from mangrove swamp sediment in Sanya, Hainan Province, China. The sediment sample was dried at room temperature, suspended in sterile distilled water and diluted in series; the suspensions were then heated in an oven at $100{ }^{\circ} \mathrm{C}$ for $60 \mathrm{~min}$. The heattreated suspensions were plated on oatmeal agar plates [International Streptomyces Project medium 3 (ISP 3); Shirling \& Gottlieb, 1966] supplemented with nalidixic acid, cycloheximide, nystatin (each at $50 \mathrm{mg} \mathrm{l}^{-1}$ ) and novobiocin $\left(25 \mathrm{mg} \mathrm{l}^{-1}\right)$. The plates were then incubated at $28{ }^{\circ} \mathrm{C}$ for $3-4$ weeks. 
Morphological characteristics were observed by light microscopy (Zeiss Axioskop) and scanning electron microscopy (FEI QUANTA 200) using cultures grown on ISP 2 medium at $28{ }^{\circ} \mathrm{C}$ for 14 days. Cultural characteristics of strain RtIII $47^{\mathrm{T}}$ were recorded after growth at $28{ }^{\circ} \mathrm{C}$ for 14 days on various agar media: ISP 2, ISP 3 , ISP 5 , ISP 7 (Shirling \& Gottlieb, 1966), potato dextrose agar (PDA; Summerell et al., 2003), Sauton's agar (Mordarska et al., 1972) and Gause inorganic agar (Gause et al., 1983). Phenotypic characteristics were examined using several standard methods: tolerance to $\mathrm{NaCl}(0-20 \%$, w/v) for growth was determined on ISP 2 agar for 14-21 days at $28{ }^{\circ} \mathrm{C}$; catalase, nitrate reduction and substrate degradation were determined by the methods of Goodfellow (1971) and Williams \& Cross (1971); carbon-source utilization was tested according to Gordon \& Mihm (1957); and utilization of amino acids as nitrogen sources was tested as described by Williams et al. (1983).

Freeze-dried cells used for chemotaxonomic analyses were obtained from cultures grown in ISP 2 broth in flasks on a rotary shaker at $125-180$ r.p.m. and $28{ }^{\circ} \mathrm{C}$ for 1 week. The isomer of diaminopimelic acid and the whole-cell sugars were analysed according to the procedures developed by Hasegawa et al. (1983). The $N$-acyl type of muramyl residue in the cell-wall peptidoglycan was tested using the method of Uchida et al. (1999). Polar lipids were extracted, examined by two-dimensional TLC and identified using procedures described previously (Minnikin et al., 1979). Menaquinones were isolated according to the methods of Groth et al. (1997). Biomass for quantitative fatty acid analysis was prepared by scraping growth from tryptic soy agar plates (Difco, BD) that had been incubated for 7 days at $28{ }^{\circ} \mathrm{C}$. The fatty acids were extracted, methylated and analysed using the standard MIDI system (Microbial Identification, Sherlock version 6.0) (Sasser, 1990) and an Agilent 6890 GC. The resulting profiles were identified using the database TSBA6, version 6.0.

Genomic DNA was extracted as described by Chun \& Goodfellow (1995). PCR-mediated amplification of the $16 \mathrm{~S}$ rRNA gene and sequencing of the PCR products were carried out as described by Nakajima et al. (1999). The 16S rRNA gene sequence of strain RtIII $47^{\mathrm{T}}$ was multiply aligned with related sequences obtained from the GenBank/EMBL/ DDBJ databases using MEGA version 4.0 (Kumar et al., 2008). The alignment was verified manually and adjusted prior to the construction of phylogenetic trees. Phylogenetic trees were reconstructed by the neighbour-joining (Saitou \& Nei, 1987) and maximum-parsimony (Fitch, 1971) methods in MEGA 4.0 (Kumar et al., 2008). Confidence values for branches of phylogenetic trees were determined using bootstrap analyses (Felsenstein, 1985) based on 1000 replications. Values for sequence similarity among the closest strains were calculated manually after pairwise alignment using the EzTaxon sever (Chun et al., 2007). PCR amplification of the gyrB gene (encoding gyrase B) and sequencing of the PCR products were carried out using primers GYF1/GYR1B and GYF3/GYR3B, as described by Garcia et al. (2010), and the resultant sequences were subjected to phylogenetic analyses using the same methods used for $16 \mathrm{~S}$ rRNA gene sequences.

The DNA G $+\mathrm{C}$ content was determined by the thermal denaturation $\left(T_{\mathrm{m}}\right)$ method (Mandel \& Marmur, 1968) using a Beckman DU-800 spectrophotometer. DNA-DNA relatedness between strain RtIII $47^{\mathrm{T}}$ and $V$. lutea YIM $013^{\mathrm{T}}$ was determined using the modified fluorometric microwell method described by Rong \& Huang (2010).

Strain RtIII $47^{\mathrm{T}}$ grew well on all media tested except ISP 5 and formed bittersweet to xanthine orange (Ridgway, 1912) substrate hyphae. It produced branched substrate hyphae bearing single spores with warty surfaces (Fig. S1, available in IJSEM Online). No aerial mycelium was formed. Growth occurred at $0-10 \%(w / v) ~ N a C l$, with good growth at $0-5 \%$. Other physiological characteristics are given in Table 1 and in the species description.

The cell-wall diamino acid of strain RtIII $47^{\mathrm{T}}$ was mesodiaminopimelic acid. The major whole-cell sugars were glucose, mannose, xylose and ribose. The acyl type of the muramyl residue was glycolyl. The predominant menaquinone was MK-9 $\left(\mathrm{H}_{4}\right)(84.8 \%)$, with minor amounts of MK$9\left(\mathrm{H}_{6}\right)(11.2 \%)$ and MK-9 $\left(\mathrm{H}_{2}\right)(4.0 \%)$. The phospholipids consisted of diphosphatidylglycerol (DPG), phosphatidylethanolamine (PE), phosphatidylinositol mannoside (PIM) and an unknown phospholipid (PL) (Fig. S2), phospholipid type PII according to Lechevalier et al. (1977). The cellular fatty acids of strain RtIII $47^{\mathrm{T}}$ were iso- $\mathrm{C}_{16: 0}(38.1 \%), 10$ methyl $\mathrm{C}_{17: 0}(12.9 \%)$, iso- $\mathrm{C}_{15: 0}(11.4 \%), \mathrm{C}_{17: 0}(8.3 \%)$, anteiso- $\mathrm{C}_{17: 0}(7.1 \%), \mathrm{C}_{17: 1} \omega 8 c(6.4 \%)$, iso- $\mathrm{C}_{17: 0}(2.4 \%)$, $\mathrm{C}_{18: 0}(2.4 \%)$, anteiso- $\mathrm{C}_{15: 0}(2.0 \%), \mathrm{C}_{17: 1} \omega 9 c(1.9 \%), 10-$ methyl $\mathrm{C}_{16: 0}(1.9 \%), \mathrm{C}_{16: 0}(1.5 \%)$, iso- $\mathrm{C}_{18: 0}(1.4 \%)$, iso$\mathrm{C}_{14: 0}(1.1 \%), \mathrm{C}_{18: 1} \omega 9 c(0.9 \%)$ and 10-methyl $\mathrm{C}_{18: 0}$ $(0.4 \%)$. This fatty acid profile was similar to that of $V$. lutea YIM $013^{\mathrm{T}}$ in our parallel test (Table S1). The G+C content of the DNA was $72.0 \mathrm{~mol} \%$. These chemotaxonomic results were largely consistent with those of members of the genus Verrucosispora, but revealed differences at the species level in polar lipids, whole-cell sugars and DNA $\mathrm{G}+\mathrm{C}$ content.

An almost-complete $16 \mathrm{~S}$ rRNA gene sequence (1484 nt) was obtained for strain RtIII $47^{\mathrm{T}}$ and compared with those deposited in public databases. A preliminary comparison indicated that it belonged to the family Micromonosporaceae. Phylogenetic analysis based on the 16S rRNA gene sequence (Fig. 1) showed that the strain formed a distinct line at the periphery of recognized members of the genera Verrucosispora and Jishengella, sharing the highest sequence similarity of $98.0 \%$ with $V$. lutea YIM $013^{\mathrm{T}}$. The strain also shared over $97.5 \%$ sequence similarity with Micromonospora olivasterospora DSM $43868^{\mathrm{T}}(97.9 \%)$, Plantactinospora mayteni YIM $61359^{\mathrm{T}}(97.9 \%)$, Salinispora tropica CNB- $440^{\mathrm{T}}(97.8 \%)$, Micromonospora peucetia DSM $43363^{\mathrm{T}}(97.7 \%)$, Micromonospora auratinigra TT1-11 ${ }^{\mathrm{T}}(97.7 \%), \quad$ V. sediminis CGMCC $4.3550^{\mathrm{T}}(97.6 \%)$ and Salinispora arenicola CNH$643^{\mathrm{T}}(97.5 \%)$. The sequence similarities to other type strains of the family Micromonosporaceae were less than $97.5 \%$, and 
Table 1. Phenotypic properties that distinguish strain RtIll $47^{\top}$ from recognized species of the genus Verrucosispora

Strains: 1, RtIII47 ${ }^{\mathrm{T}}$; 2, V. lutea YIM $013^{\mathrm{T}} ; 3$, V. sediminis CGMCC $4.3550^{\mathrm{T}} ; 4$, V. gifhornensis $\mathrm{JCM} 10457^{\mathrm{T}}$. All physiological data and fatty acid data for V. lutea YIM $013^{\mathrm{T}}$ were obtained in this study. Spore morphological characteristics and other chemotaxonomic data for recognized species are from previous studies (Rheims et al., 1998; Liao et al., 2009; Dai et al., 2010). +, Positive; w, weakly positive; -, negative.

\begin{tabular}{|c|c|c|c|c|}
\hline Characteristic & 1 & 2 & 3 & 4 \\
\hline Spore arrangement & Single & Single, pairs, clusters & Single or clusters & Single, pairs, clusters \\
\hline Spore-surface ornamentation & Warty & Smooth & Warty & Smooth, warty, hairy \\
\hline Aerial mycelium & Absent & Sparse & Sparse & Absent \\
\hline $\mathrm{NaCl}$ range $(\%, \mathrm{w} / \mathrm{v})$ & $0-10$ & $0-7$ & $0-6$ & $0-4$ \\
\hline Polar lipids ${ }^{\star}$ & PE, DPG, PIM, PL & PE, DPG, PIM, PI, PL & PE, DPG, PIM, PI, PL & PE, DPG, PIM, PS, PL \\
\hline Whole-cell sugars $\dagger$ & Glc, Man, Xyl, Rib & Glc, Xyl, Man, Rib & GlcN, Glc, Man & Man, Xyl, Rib \\
\hline Major fatty acids $(>10 \%) \ddagger$ & $\begin{array}{c}\mathrm{i}-\mathrm{C}_{16: 0}, \mathrm{i}-\mathrm{C}_{15: 0} \\
10-\mathrm{Me} \mathrm{C}_{17: 0}\end{array}$ & $\begin{array}{c}\mathrm{i}-\mathrm{C}_{16: 0}, \mathrm{i}-\mathrm{C}_{15: 0}, \mathrm{C}_{17: 1} \omega 8 c \\
10-\mathrm{Me} \mathrm{C}_{17: 0}\end{array}$ & $\mathrm{C}_{17: 0}, \mathrm{i}-\mathrm{C}_{16: 0}, \mathrm{i}-\mathrm{C}_{15: 0}$ & $\begin{array}{c}\mathrm{i}-\mathrm{C}_{16: 0}, \mathrm{i}-\mathrm{C}_{15: 0} \\
\text { ai- } \mathrm{C}_{17: 0}\end{array}$ \\
\hline DNA G $+C$ content $(\mathrm{mol} \%)$ & 72.0 & 69.3 & 66.8 & 70.0 \\
\hline Nitrite produced from nitrate & - & + & + & - \\
\hline \multicolumn{5}{|l|}{ Utilization as carbon source: } \\
\hline Trehalose & + & - & + & + \\
\hline L-Rhamnose & + & - & - & - \\
\hline D-Mannitol & + & - & + & + \\
\hline D-Fructose & + & + & - & - \\
\hline Glycerol & - & - & + & + \\
\hline D-Ribose & + & - & + & - \\
\hline Sucrose & + & - & + & + \\
\hline Inositol & + & - & + & - \\
\hline \multicolumn{5}{|l|}{ Utilization as nitrogen source: } \\
\hline L-Alanine & + & - & + & $\mathrm{W}$ \\
\hline L-Phenylalanine & - & - & + & + \\
\hline \multicolumn{5}{|l|}{ Decomposition of: } \\
\hline Adenine & + & - & + & $\mathrm{W}$ \\
\hline Casein & - & - & + & - \\
\hline Starch & - & + & + & + \\
\hline Tween 80 & - & + & + & + \\
\hline
\end{tabular}

${ }^{\star}$ DPG, Diphosphatidylglycerol; PE, phosphatidylethanolamine; PI, phosphatidylinositol; PIM, phosphatidylinositol mannoside; PS, phosphatidylserine; PL, unknown phospholipid.

$\dagger$ Glc, Glucose; GlcN, glucosamine; Man, mannose; Xyl, xylose; Rib, ribose.

‡ai, Anteiso-branched; i, iso-branched; Me, methyl.

that to Jishengella endophytica CGMCC $4.5597^{\mathrm{T}}$ was only $96.6 \%$. To evaluate the phylogenetic position of strain RtIII $47^{\mathrm{T}}$ further, gyrB gene sequences of strain RtIII $47^{\mathrm{T}}$ (1126 nt), Verrucosispora type strains (1111-1118 nt), J. endophytica CGMCC $4.5597^{\mathrm{T}}$ (1113 nt) and P. mayteni YIM $61359^{\mathrm{T}}$ (482 nt, due to the failure of PCR amplification with primers GYF3/GYR3B) were also obtained and compared with those of members of the family Micromonosporaceae deposited in public databases. Phylogenetic analysis based on the gyrB gene (Fig. 2) confirmed that strain RtIII $47^{\mathrm{T}}$ should be assigned to the genus Verrucosispora, being most closely related to $V$. lutea YIM $013^{\mathrm{T}}$, with a sequence similarity of $95.3 \%$. gyrB gene sequence similarities between strain RtIII $47^{\mathrm{T}}$ and $V$. sediminis CGMCC $4.3550^{\mathrm{T}}$ and $V$. gifhornensis JCM $10457^{\mathrm{T}}$ were 93.8 and $93.1 \%$, respectively. J. endophytica JCM $10457^{\mathrm{T}}$ also fell into the genus Verrucosispora in the gyrB gene tree, being most closely related to $V$. gifhornensis JCM $10457^{\mathrm{T}}$, with a sequence similarity of $94.3 \%$, and showing $93.2-93.5 \%$ sequence similarity to the other two Verrucosispora type strains and strain RtIII $47^{\mathrm{T}}$.

DNA-DNA relatedness between strain RtIII $47^{\mathrm{T}}$ and the closest type strain, $V$. lutea YIM $013^{\mathrm{T}}$, was $37.9 \pm 2.1 \%$. According to the revised $16 \mathrm{~S}$ rRNA gene sequence similarity threshold range of $98.7-99 \%$ (Stackebrandt \& Ebers, 2006), and a recent study that showed that, between Verrucosispora type strains, even 16S rRNA gene sequence similarity as high as $99.1 \%$ corresponded to a low DNA-DNA relatedness of less than $60 \%$ (Dai et al., 2010), hybridizations between strain RtIII $47^{\mathrm{T}}$ and the other two Verrucosispora type strains were not performed. Based on the unique 16S rRNA gene sequence, the low gyrB gene sequence similarities and the level of 


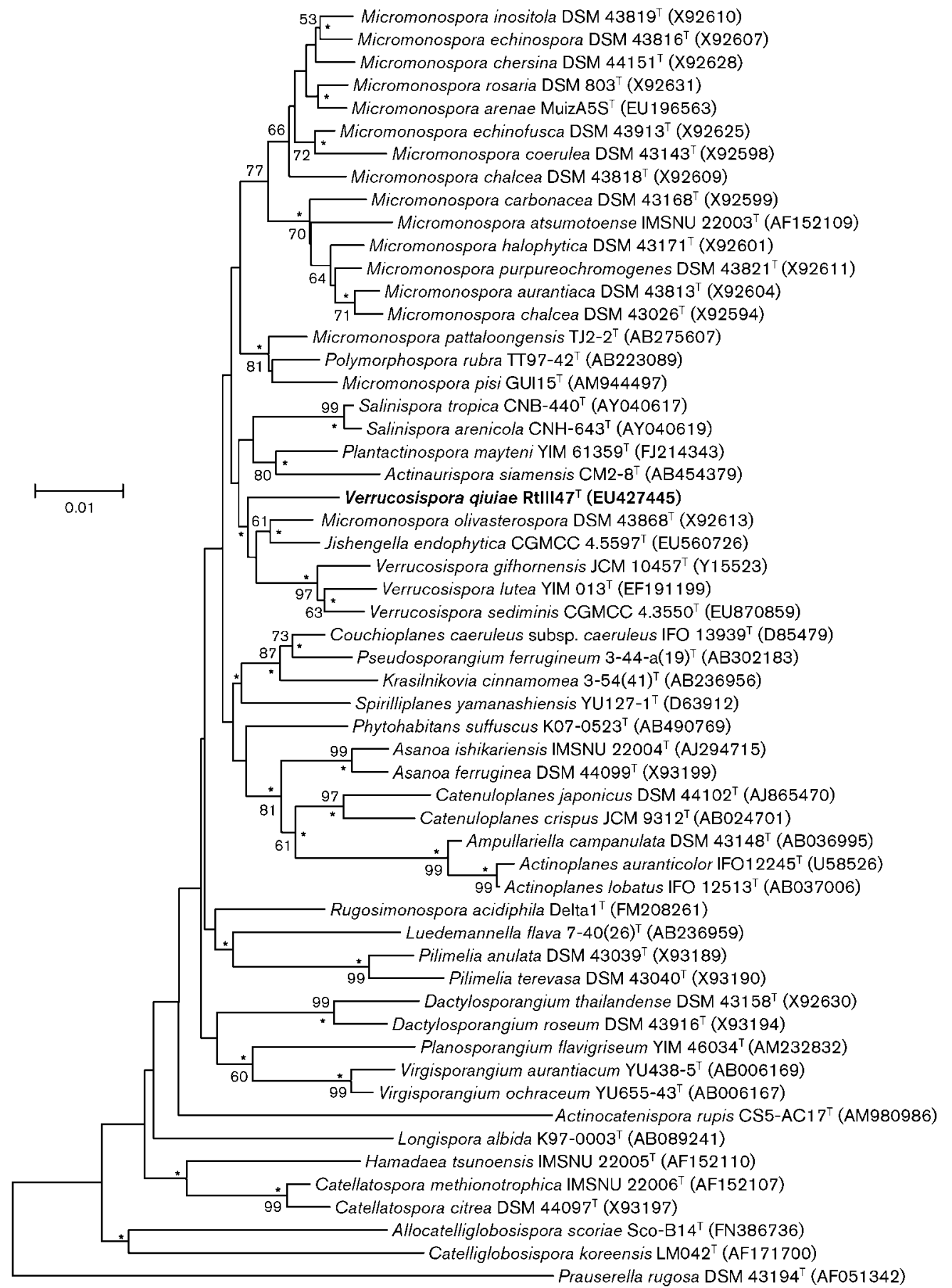

Fig. 1. Phylogenetic tree derived from $16 \mathrm{~S}$ rRNA gene sequences showing relationships between strain RtIll4 $7^{\top}$, recognized species of the genus Verrucosispora and other representatives of the family Micromonosporaceae. Asterisks indicate branches recovered with both neighbour-joining and maximum-parsimony methods. Numbers at nodes indicate levels of bootstrap support based on neighbour-joining analysis of 1000 replicates (Saitou \& Nei, 1987); only values $>50 \%$ are given. Bar, 0.01 substitutions per nucleotide position.

DNA-DNA hybridization, we propose that strain RtIII $47^{\mathrm{T}}$ is significantly different from recognized Verrucosispora species. In fact, a number of distinct phenotypic characteristics shown in Table 1 clearly distinguish strain
RtIII47 ${ }^{\mathrm{T}}$ from its closest phylogenetic relatives. Therefore, strain RtIII $47^{\mathrm{T}}$ represents a novel species of the genus, for which the name Verrucosispora qiuiae sp. nov. is proposed. 


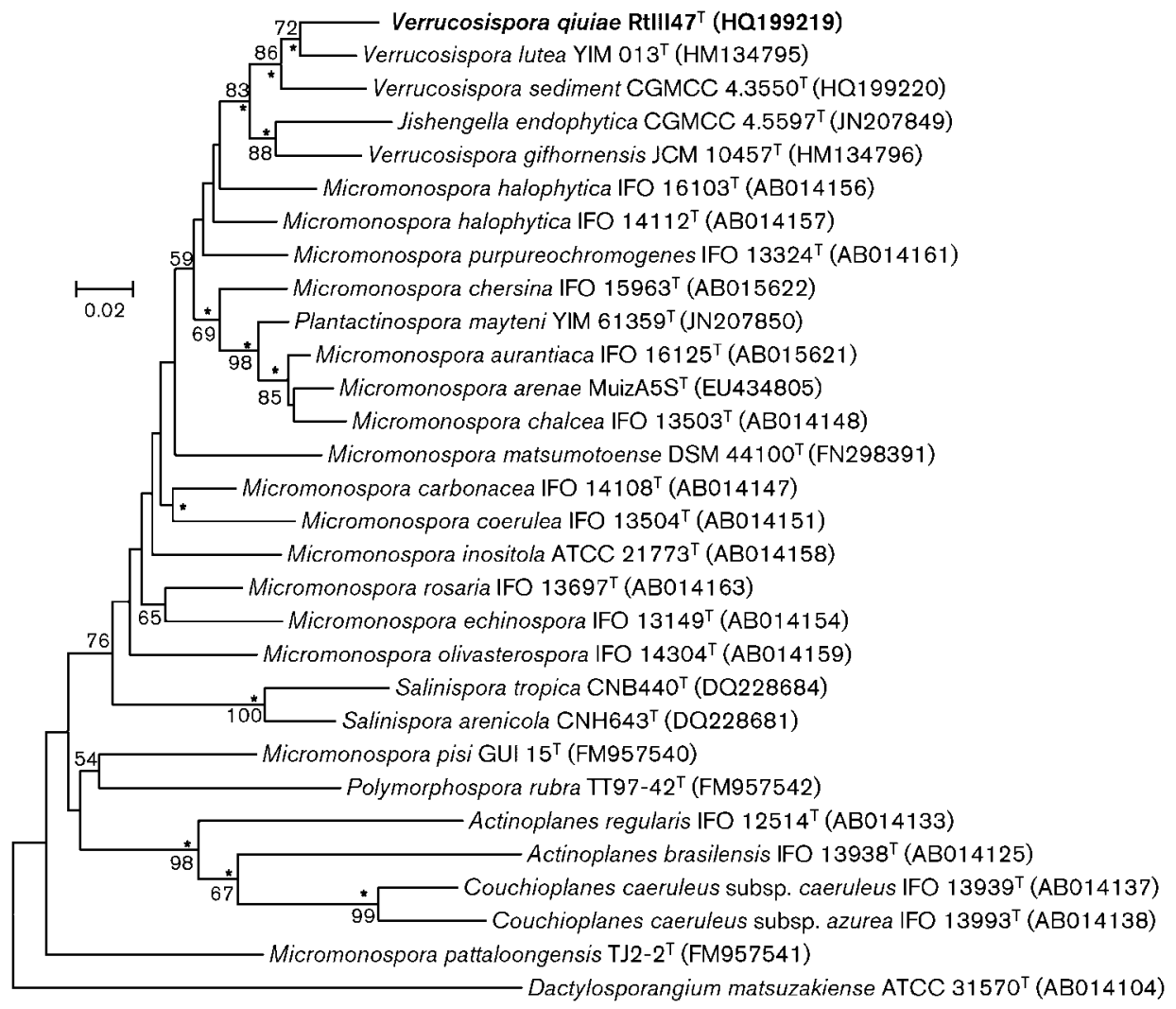

Fig. 2. Neighbour-joining phylogenetic tree based on gyrB gene sequences of strain RtIll $47^{\top}$, recognized species of the genus Verrucosispora and other related members of the family Micromonosporaceae. Sequences were $>1000 \mathrm{nt}$, except that of P. mayteni YIM $61359^{\top}$ (482 nt). Asterisks indicate branches that were also found using the maximum-parsimony method (Fitch, 1971). Numbers at nodes indicate bootstrap percentages based on 1000 replicates; only values $>40 \%$ are given. Bar, 0.02 substitutions per nucleotide position.

\section{Emended description of the genus Verrucosispora Rheims et al. 1998}

The description of the genus Verrucosispora is as given previously (Rheims et al., 1998), but with the following amendments. The diagnostic whole-cell sugar is mannose. The main phospholipids are PE, DPG and PIM. The major fatty acids $(>10 \%)$ are iso- $\mathrm{C}_{16: 0}$ and iso- $\mathrm{C}_{15: 0}$. The DNA $\mathrm{G}+\mathrm{C}$ content is $66.8-72.0 \mathrm{~mol} \%$.

\section{Description of Verrucosispora qiuiae sp. nov.}

Verrucosispora qiuiae (qi.u.i'a.e. N.L. fem. gen. n. qiuiae of Qiu, in honour of Danheng Qiu, for her devotion to the investigation of Micromonospora-like actinomycetes).

Aerobic, Gram-reaction-positive actinomycete. Forms branched, bittersweet to xanthine orange substrate hyphae, but no aerial mycelium. Single spores are formed on substrate hyphae, and the spore surface is warty. Grows well on ISP 2, ISP 3, PDA, Sauton's agar and Gause inorganic agar, but grows weakly on ISP 5 agar. No soluble pigments are produced on ISP 7 agar. Does not reduce nitrate to nitrite. Utilizes L-rhamnose, D-glucose, D-xylose, trehalose, D-galactose,
D-fructose, D-ribose, mannitol, D-arabinose, myo-inositol and sucrose as sole carbon sources, but not glycerol. L-Alanine is used as a sole nitrogen source, but L-phenylalanine is not. Negative for catalase and hydrolysis of starch and Tween 80 . Hydrolyses adenine and guanine, but not hypoxanthine, xanthine or L-tyrosine. The maximum $\mathrm{NaCl}$ concentration for growth is $10 \%(\mathrm{w} / \mathrm{v})$, with an optimum at $0-5 \%$. The cell wall contains meso-diaminopimelic acid. The predominant menaquinone is MK- $9\left(\mathrm{H}_{4}\right)$. The characteristic whole-cell sugars are mannose and xylose. The phospholipid profile is composed of DPG, PE, PIM and PL. The major $(>10 \%)$ fatty acids are iso- $\mathrm{C}_{16: 0}, 10$-methyl $\mathrm{C}_{17: 0}$ and iso- $\mathrm{C}_{15: 0}$.

The type strain, RtIII $47^{\mathrm{T}}\left(=\mathrm{CGMCC} 4.5826^{\mathrm{T}}=\mathrm{NBRC}\right.$ $106684^{\mathrm{T}}$ ), was isolated from sediment from a mangrove swamp in Sanya, Hainan Province, China. The DNA G + C content of the type strain is $72.0 \mathrm{~mol} \%$.

\section{Acknowledgements}

We are grateful to Professor Kui Hong of the Institute of Tropical Biosciences and Biotechnology, CATAS, Haikou, China, for providing the mangrove sediment sample. This work was supported by the 
Knowledge Innovation Program of the Chinese Academy of Sciences (grant no. KSCX2-EW-G-12B/ KSCX2-EW-J-6).

\section{References}

Bister, B., Bischoff, D., Ströbele, M., Riedlinger, J., Reicke, A., Wolter, F., Bull, A. T., Zähner, H., Fiedler, H. P. \& Süssmuth, R. D. (2004). Abyssomicin C-A polycyclic antibiotic from a marine Verrucosispora strain as an inhibitor of the $p$-aminobenzoic acid/tetrahydrofolate biosynthesis pathway. Angew Chem Int Ed Engl 43, 2574-2576.

Chun, J. \& Goodfellow, M. (1995). A phylogenetic analysis of the genus Nocardia with $16 \mathrm{~S}$ rRNA gene sequences. Int J Syst Bacteriol 45, 240-245.

Chun, J., Lee, J. H., Jung, Y., Kim, M., Kim, S., Kim, B. K. \& Lim, Y. W. (2007). EzTaxon: a web-based tool for the identification of prokaryotes based on $16 \mathrm{~S}$ ribosomal RNA gene sequences. Int J Syst Evol Microbiol 57, 2259-2261.

Dai, H. Q., Wang, J., Xin, Y. H., Pei, G., Tang, S. K., Ren, B., Ward, A., Ruan, J. S., Li, W. J. \& Zhang, L. X. (2010). Verrucosispora sediminis sp. nov., a cyclodipeptide-producing actinomycete from deep-sea sediment. Int J Syst Evol Microbiol 60, 1807-1812.

Felsenstein, J. (1985). Confidence limits on phylogenies: an approach using the bootstrap. Evolution 39, 783-791.

Fitch, W. M. (1971). Toward defining the course of evolution: minimum change for a specific tree topology. Syst Zool 20, 406-416.

Garcia, L. C., Martínez-Molina, E. \& Trujillo, M. E. (2010). Micromonospora pisi sp. nov., isolated from root nodules of Pisum sativum. Int J Syst Evol Microbiol 60, 331-337.

Gause, G. F., Preobrazhenskaya, T. P., Sveshnikova, G. V., Terekhova, L. P. \& Maksimova, T. S. (1983). A Guide for Determination of Actinomycetes. Moscow: Nauka (in Russian).

Goodfellow, M. (1971). Numerical taxonomy of some nocardioform bacteria. J Gen Microbiol 69, 33-80.

Gordon, R. E. \& Mihm, J. M. (1957). A comparative study of some strains received as nocardiae. J Bacteriol 73, 15-27.

Groth, I., Schumann, P., Rainey, F. A., Martin, K., Schuetze, B. \& Augsten, K. (1997). Demetria terragena gen. nov., sp. nov., a new genus of actinomycetes isolated from compost soil. Int J Syst Bacteriol 47, 1129-1133.

Hasegawa, T., Takizawa, M. \& Tanida, S. (1983). A rapid analysis for chemical grouping of aerobic actinomycetes. J Gen Appl Microbiol 29, 319-322.

Keller, S., Nicholson, G., Drahl, C., Sorensen, E., Fiedler, H. P. \& Süssmuth, R. D. (2007). Abyssomicins $G$ and $H$ and atropabyssomicin C from the marine Verrucosispora strain AB-18-032. J Antibiot (Tokyo) 60, 391-394.

Kumar, S., Nei, M., Dudley, J. \& Tamura, K. (2008). MEGA: a biologistcentric software for evolutionary analysis of DNA and protein sequences. Brief Bioinform 9, 299-306.

Lechevalier, M. P., De Bièvre, C. \& Lechevalier, H. A. (1977). Chemotaxonomy of aerobic actinomycetes: phospholipid composition. Biochem Syst Ecol 5, 249-260.

Liao, Z. L., Tang, S. K., Guo, L., Zhang, Y. Q., Tian, X. P., Jiang, C. L., Xu, L. H. \& Li, W. J. (2009). Verrucosispora lutea sp. nov., isolated from a mangrove sediment sample. Int J Syst Evol Microbiol 59, 2269-2273.

Mandel, M. \& Marmur, J. (1968). Use of ultraviolet absorbancetemperature profile for determining the guanine plus cytosine content of DNA. Methods Enzymol 12B, 195-206.
Minnikin, D. E., Collins, M. D. \& Goodfellow, M. (1979). Fatty acid and polar lipid composition in the classification of Cellulomonas, Oerskovia and related taxa. J Appl Bacteriol 47, 87-95.

Mordarska, H., Mordarski, M. \& Goodfellow, M. (1972). Chemotaxonomic characters and classification of some nocardioform bacteria. J Gen Microbiol 71, 77-86.

Nakajima, Y., Kitpreechavanich, V., Suzuki, K. \& Kudo, T. (1999). Microbispora corallina sp. nov., a new species of the genus Microbispora isolated from Thai soil. Int J Syst Bacteriol 49, 1761-1767.

Qiu, D. H., Ruan, J. S. \& Huang, Y. (2008). Selective isolation and rapid identification of members of the genus Micromonospora. Appl Environ Microbiol 74, 5593-5597.

Rheims, H., Schumann, P., Rohde, M. \& Stackebrandt, E. (1998). Verrucosispora gifhornensis gen. nov., sp. nov., a new member of the actinobacterial family Micromonosporaceae. Int J Syst Bacteriol 48, 1119-1127.

Ridgway, R. (1912). Color Standards and Color Nomenclature. Washington, DC: United States National Museum.

Riedlinger, J., Reicke, A., Zähner, H., Krismer, B., Bull, A. T., Maldonado, L. A., Ward, A. C., Goodfellow, M., Bister, B. \& other authors (2004). Abyssomicins, inhibitors of the para-aminobenzoic acid pathway produced by the marine Verrucosispora strain AB-18032. J Antibiot (Tokyo) 57, 271-279.

Rong, X. \& Huang, Y. (2010). Taxonomic evaluation of the Streptomyces griseus clade using multilocus sequence analysis and DNA-DNA hybridization, with proposal to combine 29 species and three subspecies as 11 genomic species. Int J Syst Evol Microbiol 60, 696-703.

Saitou, N. \& Nei, M. (1987). The neighbor-joining method: a new method for reconstructing phylogenetic trees. Mol Biol Evol 4, 406425.

Sasser, M. (1990). Identification of bacteria by gas chromatography of cellular fatty acids, MIDI Technical Note 101. Newark, DE: MIDI Inc.

Schneider, K., Keller, S., Wolter, F. E., Röglin, L., Beil, W., Seitz, O., Nicholson, G., Bruntner, C., Riedlinger, J. \& other authors (2008). Proximicins A, B, and C-antitumor furan analogues of netropsin from the marine actinomycete Verrucosispora induce upregulation of p53 and the cyclin kinase inhibitor p21. Angew Chem Int Ed Engl 47, 3258-3261.

Shirai, M., Okuda, M., Motohashi, K., Imoto, M., Furihata, K., Matsuo, Y., Katsuta, A., Shizuri, Y. \& Seto, H. (2010). Terpenoids produced by actinomycetes: isolation, structural elucidation and biosynthesis of new diterpenes, gifhornenolones A and B from Verrucosispora gifhornensis YM28-088. J Antibiot (Tokyo) 63, 245-250.

Shirling, E. B. \& Gottlieb, D. (1966). Methods for characterization of Streptomyces species. Int J Syst Bacteriol 16, 313-340.

Stackebrandt, E. \& Ebers, J. (2006). Taxonomic parameters revisited: tarnished gold standards. Microbiol Today 33, 152-155.

Summerell, B. A., Salleh, B. \& Leslie, J. F. (2003). A utilitarian approach to Fusarium identification. Plant Dis 87, 117-128.

Uchida, K., Kudo, T., Suzuki, K. \& Nakase, T. (1999). A new rapid method of glycolate test by diethyl ether extraction, which is applicable to a small amount of bacterial cells of less than one milligram. J Gen Appl Microbiol 45, 49-56.

Williams, S. T. \& Cross, T. (1971). Actinomycetes. Methods Microbiol 4, 295-334.

Williams, S. T., Goodfellow, M., Alderson, G., Wellington, E. M. H., Sneath, P. H. A. \& Sackin, M. J. (1983). Numerical classification of Streptomyces and related genera. J Gen Microbiol 129, 1743-1813. 